\title{
メカニカルセンサー膜
}

\author{
篠 原 譲 司*, 国 京 利 一**
}

\section{Thin Film Sensors}

Joji SHINOHARA* and Toshikazu KUNIKYO**

Key Words : Sensor, Thin Film Sensor, Hot Film Sensor, Strain Gauge

機械要素部材に作用する応力, 温度, 圧力などをできるだけ実際に近い状態で計測評価するために, 直接その部材の表面に PVD法でコーティングする薄膜センサーを開発している，その適用例を含めて 紹介する。

\section{1.はじめに}

機械部品の表面に直接一体型センサーを形成すること により, ょり正確に機械部品の歪み, 温度, 圧力, 表面 層流れなどを計測することを目的として薄膜センサーを 開発している。

最近の機械産業の広がりに応じて極限環境を始めとし て, 様々な使用環境に対応した産業機器の開発が求めら れており, 機器を構成する一つ一つの部品に対する設計 要求む厳しいものとなり機械要素部材に作用する応力, 温度，圧力などをできるだけ実際に近い状態で計測評価 することが求められている。このため計測対象部材の表 面に直接 PVD法（スパッタリング法などの物理蒸着法） による薄膜コーティングで, センサーを形成する薄膜セ ンサーを開発したので以下に紹介する。

薄膜センサーは, 今までの貼りゲージなどでは十分計 測できなかった微小部分の情報や極薄い機械部品の歪み, 温度, 接触部の圧力などの測定を対象とし, 真空薄膜法 により厚さ $5 \sim 6$ ミクロンの厚みのセンサを直接機械部 品の表面に形成している。例えば, 航空機エンジン圧縮 機のブレードの歪み計測用ゲージは, 従来は数ミリの耐 熱用フリーフィラメント型歪みゲージをアルミナ溶射に よりブレードの上に貼り付けていたが, ブレード自身の 厚みとゲージ取り付け部の厚みが同等位までになりブレー ド自身の振動特性や空力特性を変えてしまうことが多く

*石川島播磨重工業㑣（テ135 東京都江東区豊洲3-1-15） Ishikawajima-Harima Heavy Industries Co., Ltd. (1-15, Toyosu 3-chome, Koto-ku, Tokyo 135)

**石川島播磨重工業(侏（广190-12 東京都西多摩郡瑞穂町殿ヶ 谷229)

Ishikawajima-Harima Heavy Industries Co., Ltd. (229, Tonogaya, Mizuho-machi, Nishitama-gun, Tokyo 190-12)
より薄型のセンサの開発が検討されていた。

\section{2. 薄膜センサーの概要}

真空を利用した薄膜形成技術の進歩により，処理する 機械部材に過度の機械特性を損なうょうな熱的負荷をか けることなく低温で, 合金, 化合物, 半導体などの材料 の薄膜合成が可能となり, 使用条件の厳しい切削工具の 硬質皮膜処理や耐食, 耐熱機能化などの表面処理に真空 薄膜被覆処理が使われるようになってきた。この薄膜を 形成する方法として真空蒸着, スパッタリング, イオン プレーティング法などの物理蒸着法があり，これらの技 術を使って直接対象部材に形成した薄膜センサー ${ }^{1)}$ が 注目されている。

薄膜センサーの基本構成を図 1 に示す。計測対象とな る機械部材は一般には金属部品が多いので, センサーの 膜を作る前に電気絶縁をとるため表面に最初, アルミナ, 二酸化ヶイ素などのセラミックス膜や有機皮膜で絶縁膜 コーティングする必要がある。その上に, 目的のセンサー 皮膜, 例えば歪みセンサーではニッケルクロム薄膜など の合金膜をコーティングし，ゲージパターン加工を行う。 さらに信号線との結線につごうのよい位置まで, 電極膜

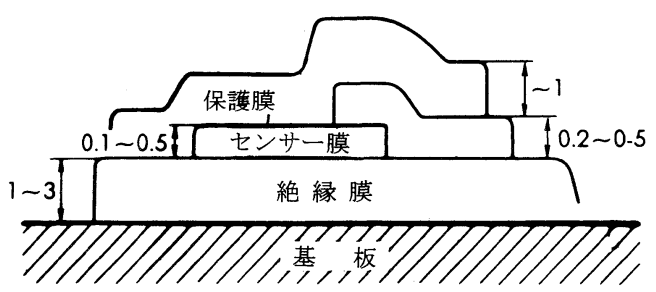

図 1 薄膜センサーの構成 (単位 : $\mu \mathrm{m}$ ) 
として金，銅などを薄膜で配線する。薄膜センサーの使 用環境に応じて耐熱性, 而久性を付加するため, センサー および配線をセラミックス材による保護膜でコーティン グすることも可能である。薄膜センサーの寸法例として センサーパターンで数十ミクロン〜数ミリメートル, 厚 さは数ミクロン程度である。

ここでは薄膜センサーを形成する方法として，セラミッ クスや合金の薄膜形成にすぐれ，原材料に近い皮膜組成 の得られるスパッタリング法を用いている。これは, 真 空プラズマ中で生成されたイオンを皮膜となる材料に衝 突させ, その運動エネルギーで原材料原子あるいは分子 を吒き出し, 対象部品の表面に付着, 成膜させる方法で ある。

\section{3. 薄膜センサーの適用例}

\section{1 薄膜歪みセンサー}

薄膜センサーの適用例として, 先ず航空機エンジン圧

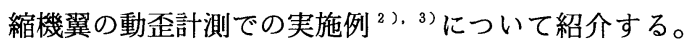
実際に曲面からなる翼材の表面に, 歪みゲージの数十ミ クロンのセンサーパターンを形成しようとすると金属表 面の粗さや湾曲した表面に，半導体 IC と同じようなプ ロセスで微細な回路を形成するのは個々の形状に合わせ た工夫が必要である。

薄膜歪みセンサーの加工方法は, 先ず基板の表面に厚 さ数ミクロンのセンサーを形成するため, 対象となる機 械部品の表面を平均荒さ 0.2 ミクロン以下となるように バフ研磨により仕上げる。絶縁膜には比較的高温でも絶 縁性能の良いアルミナ膜を $3 \sim 5$ ミクロン厚さに形成す る。アルミナ膜のスパッタリング条件は圧力 $0.67 \mathrm{~Pa}$, スパッタリングパワー密度 $5.7 \mathrm{~W} / \mathrm{cm}^{2}$, 成膜速度 $2 \mu \mathrm{m}$ $/ \mathrm{h}$ で, 絶縁性能として $10^{6} \mathrm{~V} / \mathrm{cm}$ を得た。歪みゲージ部 はニッケル・クロム $(80 \mathrm{Ni}, 20 \mathrm{Cr})$ を 0.5 ミクロン厚さ に形成し，フォトレジスト法によりゲージパターン加工 して, 120〜350オームのゲージ抵抗とした。ゲージの 抵抗は市販のそれに近い值とし，既存の計測器を利用で きるようにしている。保護のためにセンサー部を 1 ミク ロンのアルミナ膜でコーティングし, 薄膜センサー全体 の厚さを 5 〜 6 クロンとした。

翼単体に薄膜センサーを試作し, 裏側に貼った市販貼 り歪みゲージで行った予備出力比較試験で良好な結果が 得られたので, 航空機エンジン軸流圧縮機の動, 静翼に 薄膜歪みゲージを形成し実計测試験を行った。図 2 に入 り口案内翼に形成した薄膜センサーの配置例を示す。ま た, 図 3 に航空機エンジン圧縮機翼に形成した薄膜歪み ゲージの出力を周波数分析した例として, キャンベル線 図を示す。翼の一次曲げ固有振動数との共振データなど, 実機試験（回転数6000 18000rpm）で従来の歪みゲー ジと同様の振動歪みが計测でき, さらに高温環境での計

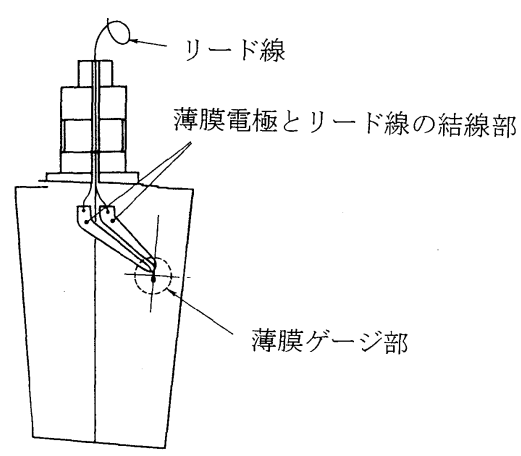

図 2 翼に形成した薄膜歪みセンサー配置例

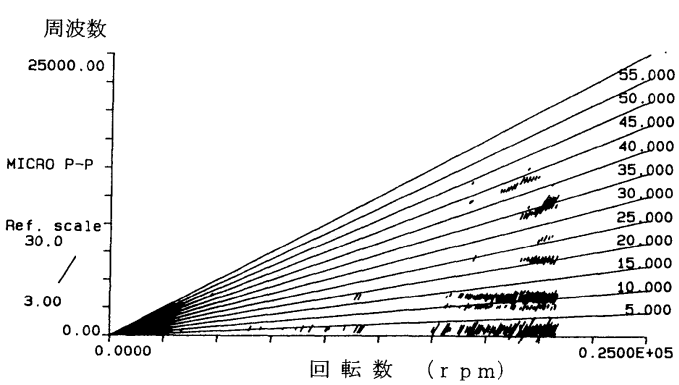

(a) 薄膜歪みセンサー

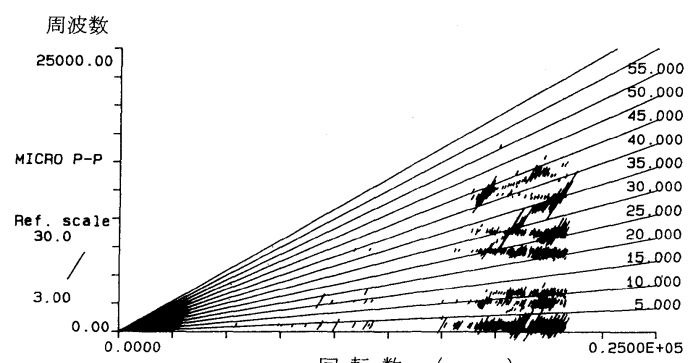

回転数 ( $\mathrm{r} \mathrm{p} \mathrm{m})$

$0.2500 \mathrm{E}+05$

（b）別翼に形成した従来型ゲージ

図 3 歪み出力によるキャンベル線図 (入り口案内翼)

測, より微小領域の計測への可能性を拓く屯のとして有 望なことが確認されている。現在では, 800 $900^{\circ} \mathrm{C}$ 高 温環境で動作可能な薄膜歪みセンサーの開発に取り組ん でいる。

\section{2 エンジン翼面上の境界層流れの計測}

2 次元に多点配列したホットフィルムセンサーを, 航 空機エンジンタービンノズル入り口案内翼の面上に薄膜 法で形成し, 低レイノルズ数領域での境界層流れの計測

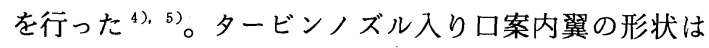
翼表面の空気流れを 3 次元解析して形状が決められるが, 翼は曲面を複合させたような形状をしており, 複雑曲面 


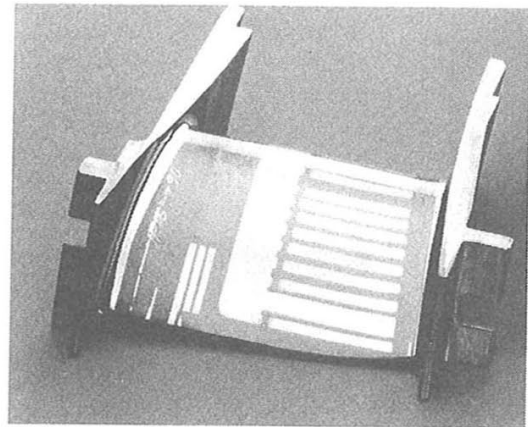

（a）翼に形成した薄膜センサーの外観

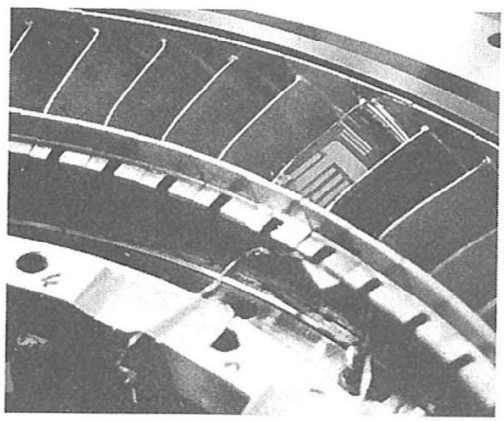

（b）試験機に組み込んだ薄膜センサー翼

図 4 薄膜ホットフィルムセンサーの供試例

上の気体流れ計測は難しい。従来, 一部ではポリフィル ムの上に作られた市販のホットフィルムセンサーを翼な どの対象物の表面に接着剤で貼って使われていた。この 場合センサーのゲージ部の厚みが50ミクロン以上にも なり，测定自体ゲージが部品の表面で境界首流れを妨げ ないように工夫して使う必要があった。このホットフィ ルムセンサーの薄膜化に取り組み, 3 次元形状の複雑曲 面に微細センサーを加工する技術, 対象部品形状での境 界首流れに合わせたゲージ寸法, 形状の薄膜ホットフィ ルムセンサーを開発し適用した。この結果, タービンノ ズル入り口案内翼の表面に直接薄膜ホットフィルムセン サ一を翼に沿って10個二次元的に配列し，境界渞流れ をより正確に計測できることが確認された。

薄膜ホットフィルムセンサーの構成は, ゲージ部を翼 基板から電気的, 熱的に絶縁するためにポリイミド薄膜 を約 3 ミクロン厚に成膜し，この上にマイクロゲージを 形成した。図 4 に薄膜ホットフィルムセンサーを形成し た翼と試験機への組み込み写真を示す。ホットフィルム センサーのゲージ部には適度の電気抵抗と, 大きな温度 電気抵抗係数を持つニッケルをスパッタリング法を用い て 0.1 ミクロン厚に薄膜化して用い, 電極りード膜には 金薄膜を用いた。薄膜ホットフィルムセンサーは表面を 気流中の微小粒子や酸化，腐食などから保護するために
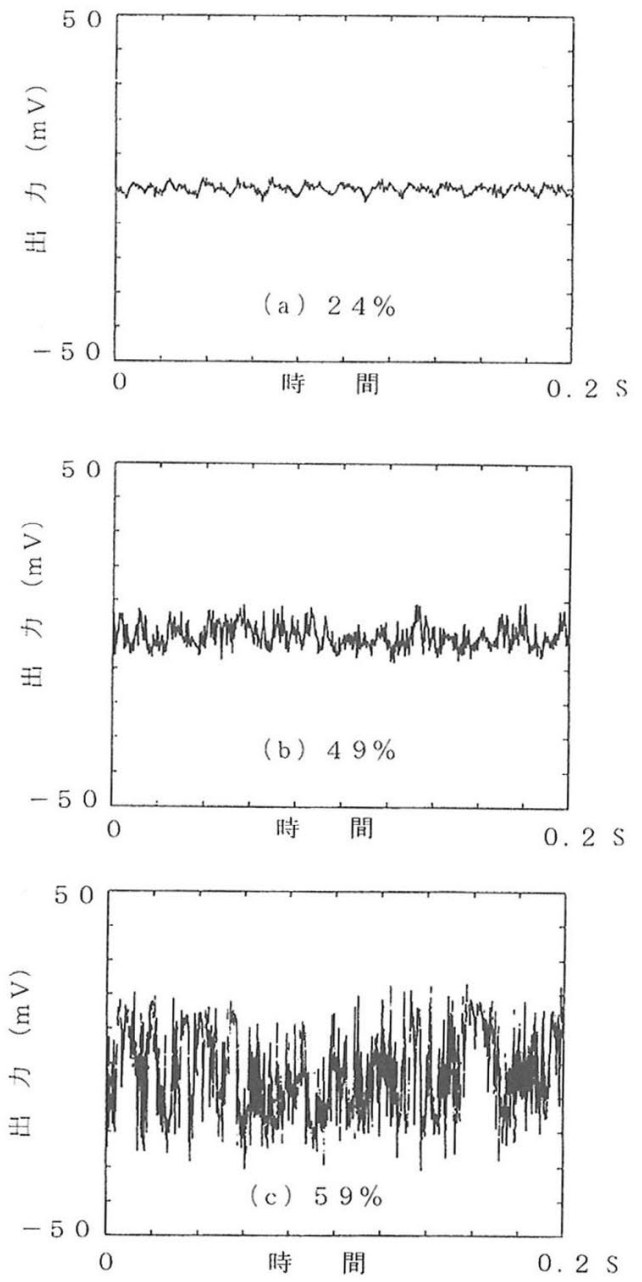

図 5 ホットフィルムセンサーの出力例

アルミナ膜でオーバーコートしている。各皮膜のスパッ タリング条件は, 背圧 $1.3 \times 10^{-1} \mathrm{~Pa}$, プラズマエッチン グ 400Wで 2 分間, スパッタリング圧力0.67Pa (Ar), 成膜時のパワー密度はそれぞれ，ゲージ膜 $(\mathrm{Ni}): 5.5 \mathrm{~W}$ $/ \mathrm{cm}^{2}$, 金電極膜 $(\mathrm{Au}): 2.7 \mathrm{~W} / \mathrm{cm}^{2}$, 保讙膜（アルミ ナ）: $4.1 \mathrm{~W} / \mathrm{cm}^{2}$ であった。薄膜ホットフィルムセンサー を一つの流路を挟んで 1 対のタービンノズル案内翼の互 いに対向し合った面にそれぞれ成膜し, 試験機に組み込 みリグテストで実機性能確認試験を行った。図 5 (a)〜 (c) は翼の背側に形成したゲージ配列の出力例を示した あので, 図中に示したパーセントの数字は, 翼表面のリー ド側先端から流れに沿って翼端までの距離を 100 とした 時の, 各ゲージのリード側からの位置を表わしている。 図中, $\pm 5 \mathrm{mV}$ 出力以下は流れのない状態で, 実機試験 より翼表面の境界層流れの状態を計測できることが確認 された。ゲージ位置（図中 (a)）の24\% 31\%では首流 
状態を示しており，37\%〜(b) の 49\%の位置では出力が 上がってきており，層流から乱流に遷移が始まっている。 (c) の $59 \%$ の位置近傍で乱流の生成はピークを示し， 82 \%の位置まで境界層流れは乱流状態であることが測定さ れた。ホットフィルムセンサーの計測結果と, 従来行っ ていた油膜可視化法による翼表面流れパターンの結果と 非常に良い一致がしており，薄膜センサーを使った計測 法が有効なことが確認された。さらに，ホットフィルム センサーの薄膜化は, リアルタイムでその場計測が可能 で，センサー配列を選定することでより微細な流れパター ンの把握が可能となることが期待される。

\section{4.むすび}

新しい計測技術として，真空を利用した薄膜プロセス で形成した薄膜センサーの回転機械への適用例を, 航空 機エンシン翼の特性計測に薄膜歪みセンサー, ホットフィ ルムセンサーについてここに紹介した。薄膜センサーの 特徵は, 微小化して対象としている部分に直接形成でき ることから局所情報を高精度で取得できること，接着郕
を使用しないことにより耐久性, 信頼性が高く, 高温に 耐えることにある。

今後, 薄膜センサーはその有效性が実証されるにつれ て，これまで十分に計測できなかった機械部品の狭小部 や高温環境に対して，広く活用されていくであろう。

(1995-5-15 受理)

\section{文献}

1) P. M. Niskode, J. Foster and C. B. Jones ; ASME Md25 (1980)

2) H. Aono, J. Shinohara, T. Chikata and Y. Hagiwara; SEM Spring Conference on Experimental Mechanics (1985)

3) Y. Ikegami, J. Shinohara and S. Nagano; IHI Engineering Review, 23, Na 1 (1990)

4) S. C. Cook, T. Kunikyo and J. Shinohara ; International Symposium on Air Breathing Engines (1990)

5) F. Ida, J. Shinohara, T. Kunikyo and K. Nakasu ; 18th AIAA Aerospace Ground Testing Conference June, p.20-23 (1994)

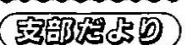

(a)

\section{関東支部・電鋳金型の表面処理専門部会共催による 東京湾横断道路中央トンネル工事現場見学会報告}

去る 4 月26日（水）に，本協会・関東支部（支部長 茨城大学 浦尾亮一) と電鋳金型の表面処理専門部会 （代表幹事 松本誠臣）共催による東京湾中央部に浮かぶ 人工島工事現場見学会が行われた。

今回の見学会は異色の見学会にもかかわらず38名の 参加者があった。川崎駅より市バスで東扇島にある共同 企業体現場作業所へ，大成建設怵本社より技術部長・次 長の出席の中，中村隆良作業所長より工事概要の説明が あった。その後，作業服に着替えへルメットをかぶり， 救難用具を装着し 2 隻の連絡船で人工島へ向かった。天 気は軖り空で波は少しうねりがあり中には気分の悪そう な方も見られた。この海低下を道路が通ると考えると不 思議に思うぐらいの距離である。

東京湾横断道路は, 東京湾の中央部を横断し, 神奈川 県川崎市と千葉県木更津市を結ぶ，全長 $15.1 \mathrm{~km}$ の自動 車専用道路で平成 10 年完成予定であります。人工島は, 川崎港沖合 $5 \mathrm{~km}$ で水深 $28 \mathrm{~m}$ に位置し, 直径 $98 \mathrm{~m}$ の円

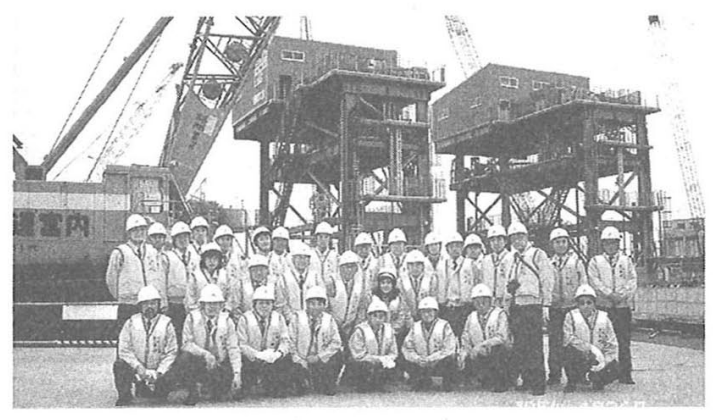

筒形の構築物で，その広さは東京ドームとほぼ同じ大き さであるとのことです。シールド工事期間中はシールド マシンにより木更津と川崎に向けて海面下約 $44 \mathrm{~m}$ （水 圧 $\mathrm{kgf} / \mathrm{cm}^{2}$ ） を泥水式シールド工法で 4 本のトンネル を構築する発進基地として，完成後は換気立抗としての 機能をはたすそうです。

人工島では，見るあのすべてビッグである。エレベー 夕ーで海底 $22 \mathrm{~m}$ まで下り, 1 週間後には木更津に向け て発進する直径 $14 \mathrm{~m}$ シールドマシンや泥水処理設備・ コンクリートプラント船・それらをコントロールするコ ンピュータルームなどを見学した。

最後に, 大阪 衛課長より塩害対策やシールドマシン の切削工具などの話と質疑応答がなされた。

(武蔵工業大学 中澤洋二) 